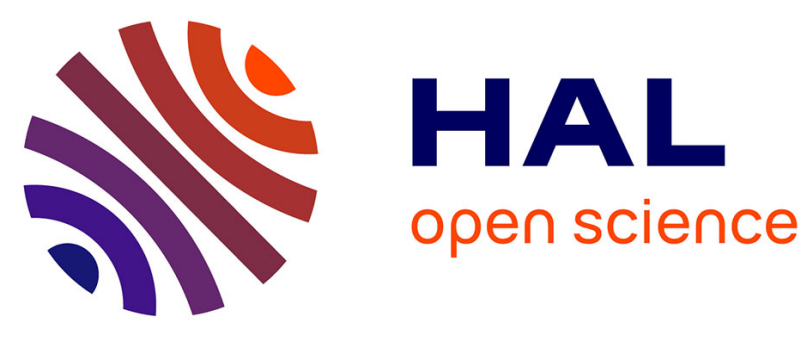

\title{
Impact of Increased Right Atrial Size on Long-Term Mortality in Patients With Heart Failure Receiving Cardiac Resynchronization Therapy
}

Alexandre Altes, Ludovic Appert, François Delelis, Yves Guyomar, Aymeric Menet, Pierre-Vladimir Ennezat, Raphaëlle A Guerbaai, Pierre Graux, Christophe Tribouilloy, Sylvestre Maréchaux

\section{To cite this version:}

Alexandre Altes, Ludovic Appert, François Delelis, Yves Guyomar, Aymeric Menet, et al.. Impact of Increased Right Atrial Size on Long-Term Mortality in Patients With Heart Failure Receiving Cardiac Resynchronization Therapy. American Journal of Cardiology, 2019, 123, pp.936 - 941. 10.1016/j.amjcard.2018.12.015 . hal-03486664

\section{HAL Id: hal-03486664 https://hal.science/hal-03486664}

Submitted on 20 Dec 2021

HAL is a multi-disciplinary open access archive for the deposit and dissemination of scientific research documents, whether they are published or not. The documents may come from teaching and research institutions in France or abroad, or from public or private research centers.
L'archive ouverte pluridisciplinaire HAL, est destinée au dépôt et à la diffusion de documents scientifiques de niveau recherche, publiés ou non, émanant des établissements d'enseignement et de recherche français ou étrangers, des laboratoires publics ou privés.

\section{(ㅇ)(1) $\$$}

Distributed under a Creative Commons Attribution - NonCommerciall 4.0 International 


\section{Impact of Increased Right Atrial Size on Long Term Mortality in Patients With Heart Failure Receiving Cardiac Resynchronization Therapy}

Alexandre Altes ${ }^{\mathrm{a}} \mathrm{MD}$, Ludovic Appert ${ }^{\mathrm{a}} \mathrm{MD}$, François Delelis ${ }^{\mathrm{a}} \mathrm{MD}$, Yves Guyomar ${ }^{\mathrm{a}} \mathrm{MD}$, Aymeric Menet $^{\mathrm{a}}$ MD PhD, Pierre-Vladimir Ennezat ${ }^{\mathrm{b}}$ MD PhD, Raphaëlle A Guerbaai ${ }^{\mathrm{c}}$ MsC RN, Pierre Graux ${ }^{\mathrm{a}}$ MD, Christophe Tribouilloy ${ }^{\mathrm{d}, \mathrm{e}} \mathrm{MD} \mathrm{PhD}$ and Sylvestre Maréchaux ${ }^{\mathrm{a}, \mathrm{e}} \mathrm{MD} \mathrm{PhD}^{* *}$

a Université Lille Nord de France, GCS-Groupement des Hôpitaux de l'Institut Catholique de Lille, Laboratoire d'échocardiographie, service de cardiologie Nord, Centre des Valvulopathies, Faculté de Médecine et de Maïeutique, Université Catholique de Lille, Lille, France

${ }^{b}$ Centre Hospitalier Universitaire de Grenoble, Service de cardiologie, Grenoble, France

${ }^{\mathrm{c}}$ Department Public Health (DPH), Faculty of Medicine, University of Basel, Basel, Switzerland.

${ }^{\mathrm{d}}$ Centre Hospitalier Universitaire d'Amiens, Amiens, France

${ }^{\mathrm{e}}$ INSERM U 1088 Université de Picardie, Amiens, France

Running head: Right atrial volume before CRT

** Corresponding author. Cardiology department, GCS- Groupement des Hôpitaux de l'Institut Catholique de Lille, Faculté libre de médecine / Université Catholique de Lille, Rue du Grand But, 59160 Lomme, France. Tel: +33 320225057.

E-mail address: sylvestre.marechaux@ yahoo.fr (S. Maréchaux).

\section{Acknowledgments}

The authors thank Camille Trouillet, Domitille Tristram RN, and Amélie Lansiaux MD PhD for their assistance in the completion of the study

\section{Disclosure of interest}

The other authors declare that they have no conflicts of interest concerning this article.

\section{Word count 1926}




\section{ABSTRACT}

The ability to visualize the right atrium (RA) by echocardiography allows a quantitative, highly reproducible assessment of the RA volume (RAV). The aim of this study is to evaluate the relationship between RAV and long-term mortality in a prospective cohort of HF-rEF patients in sinus rhythm receiving cardiac resynchronization therapy (CRT). 172 patients were included. The right atrium volume index (RAVI) was calculated using Simpson's method from the apical four-chamber view and indexed to body surface area. The relationship between RAVI and mortality during follow-up was studied. Median follow-up was 68 months (interquartile range $62-73$ months). Mean RAVI was $27 \pm 14 \mathrm{ml} / \mathrm{m}^{2}$ (IQR 22-33 $\mathrm{mL} / \mathrm{m}^{2}$ ). Cumulative 5-year all-cause mortality was $22 \pm 6 \%$ in patients with RAVI $\leq 19 \mathrm{ml} / \mathrm{m}^{2}$, $24 \pm 6 \%$ for RAVI 19 to $29 \mathrm{~mL} / \mathrm{m}^{2}$ and $58 \pm 7 \%$ for RAVI $>29 \mathrm{~mL} / \mathrm{m}^{2}$ (p for trend $<0.001$ ). After adjustment on clinical and echocardiographic predictors of outcome including indices of right ventricular function, there was a significant increase in overall mortality risk with increasing RAVI (adjusted hazard ratio [HR] 1.02 [95\% confidence interval $(\mathrm{CI}), 1.00-1.03$ ], per 1 $\mathrm{ml} / \mathrm{m} 2$ increment; $\mathrm{p}=0.042$ ). Patients in the highest tertile (RAVI $>29 \mathrm{ml} / \mathrm{m}^{2}$ ) had significantly greater risk of death compared with those with RAVI $\leq 29 \mathrm{~mL} / \mathrm{m}^{2}$ (adjusted HR 2.06 [95\% CI, 1.15-3.50]; $\mathrm{p}=0.014)$. In conclusion, RA enlargement is a powerful and highly reproducible independent predictor of long-term mortality in patients with $\mathrm{HFrEF}$ in sinus rhythm receiving CRT.

Keywords : right atrium, heart failure, cardiac resynchronization therapy, outcome 


\section{INTRODUCTION}

Right ventricular (RV) dysfunction is a powerful independent factor of poor prognosis in patients with heart failure (HF) and reduced ejection fraction (HFrEF). ${ }^{1,2} \mathrm{RV}$ dysfunction has also been associated with an increased risk of long-term mortality in HFrEF patients receiving cardiac resynchronization therapy $(\mathrm{CRT})^{3}$, but does not seem to be the right predictor to determine response to CRT. ${ }^{4}$ Accurate echocardiographic assessment of RV systolic function is challenging and relies mainly on the assessment of RV longitudinal function. ${ }^{5}$ In contrast, the ability to visualize the right atrium (RA) allows a quantitative, highly reproducible assessment of the RA volume. Right atrium volume indexed to body surface area (RAVI) has been associated with adverse outcome in patients with pulmonary hypertension ${ }^{6}$ and with RV systolic dysfunction in HFrEF patients. ${ }^{7}$ However, the impact of RA dilatation on mortality in patients with HFrEF has not been investigated. To address this issue, we studied here the relationship between RAVI and outcome in a prospective cohort of HFrEF patients receiving CRT.

\section{METHODS}

The present cohort consisted of ambulatory patients with HFrEF in sinus rhythm referred to Hôpital Saint Philibert (Lille Catholic University), Lomme, France, for CRT device implantation between December 2010 and January 2015, in whom echocardiographic evaluation allowed reliable measurement of RA volume. CRT was indicated according to current heart failure guidelines. Exclusion criteria included: (i) myocardial infarction, acute coronary syndrome, or coronary revascularization in the past three months; (ii) primary mitral or aortic valve disease; (iii) atrial fibrillation. Patients received a maximum tolerated dose of heart failure treatments. Blood was sampled for serum creatinine and plasma BNP levels before CRT device implantation. The study was approved by the Lille Catholic University 
ethics committee for non-interventional research. Informed consent was obtained at the time of enrollment from all patients.

Comprehensive transthoracic echocardiography was performed in all patients the day before CRT implantation using a GE Vivid E9 ultrasound system (General Electric healthcare, Velizy, France) according to current guidelines. ${ }^{8}$ All images and loops were stored and measured later by an independent investigator blinded to the clinical data. Right atrium volume (RAV) was calculated using Simpson's method from the apical four-chamber view, by tracing the inner border of the right atrium at end systole. ${ }^{8}$ Volumes are computed by using the disks summation technique. RAVI was derived by dividing the RAV by body surface area. Significant mitral regurgitation (MR) was considered if effective regurgitant orifice area (EROA) was $\geq 10 \mathrm{~mm}^{2} .{ }^{9}$ Significant tricuspid regurgitation (TR) was considered if $\geq$ moderate to severe. ${ }^{10}$ To assess the interobserver variability of RAVI, stored echocardiograms from 20 randomly selected patients were separately studied by two readers (S.M and A.A), during two reading sessions at 1 month interval. Three cardiac cycles were measured and averaged from the same echocardiographic study, in a random order, blinded to previous measurements.

During follow-up, patients were monitored by their general physicians. Events were ascertained by clinical interviews and/or by means of phone calls to physicians, patients, and (if necessary) next of kin. Death status was available for all participants. The primary endpoint of the study was overall mortality and secondary endpoint was cardiovascular mortality. Cardiovascular mortality was considered if death was related to HF, myocardial infarction, arrhythmia, or sudden death.

Quantitative data are presented as mean \pm standard deviation or median [25th-75th percentile]. Qualitative data are presented as absolute numbers and percentages. Continuous 
variables for the three groups of RAVI tertiles were compared using one-way analysis of variance (for normally distributed variables) or Kruskall-Wallis test (for skewed variables). Comparison of categorical variables was carried out using a chi-square test or a Fisher exact test as appropriate. Intra and interobserver variability was expressed by means of the intraclass correlation coefficient (ICC) with its 95\% confidence interval [CI]. Median followup time was obtained using the reverse Kaplan-Meier method. Event rates +/- SEs of the overall population and of the three groups were estimated according to the Kaplan-Meier method and compared using log-rank tests. Univariate and multivariate analyses of time to events were performed using Cox proportional-hazards models. We did not use model building techniques; covariates were entered in the models which were considered of potential prognostic impact on an epidemiologic basis. These covariates were age, coronary artery disease, LVEF, QRS width, left bundle branch block (LBBB), functional class NYHA III/IV, creatinine serum and TAPSE or S'. Because of skewness, BNP data were log-transformed when added to multivariable models. In case of missing values $(<10 \%$ of the data used in this study), the multivariate imputation by chained equations algorithm in $\mathrm{R}$ was used. All pvalues are the results of two-tailed tests. For all analyses, a P value of $<0.05$ was considered statically significant. Data were analyzed with SPSS version 20.0 (IBM, Amonk, New York) and R version 3.4.4 (R Foundation for Statistical Computing, Vienna, Austria).

\section{RESULTS}

One hundred and seventy-two patients were enrolled in the present study. Patient's characteristics, overall and according to RAVI tertiles are detailed in Table 1. Mean RAVI was $27 \pm 14 \mathrm{ml} / \mathrm{m}^{2}$ (median, $23 \mathrm{ml} / \mathrm{m}^{2}$; IQR, 17-33 ml/m²). Intra- and interobserver variability were good for RAVI (intraclass correlation coefficient: 0.98 [95\% CI, 0.95-0.99], and 0.95 
[95\% CI, 0.87-0.98], respectively). Patients in the highest tertile of RAVI were older, more symptomatic according to functional class NYHA, had a higher heart rate and lower systolic blood pressure, were more treated by diuretics, had lower implantable cardioverterdefibrillator rates, and had higher creatinine and BNP serum levels. Patients in the highest tertile had a lower EF and a more depressed RV systolic function, higher LV and LA volumes, LV filling pressures and pulmonary pressure (Table 1). RAVI modestly correlated with BNP at inclusion $(\mathrm{r}=0.43 ; \mathrm{p}<0.001)$.

Median follow up was 68-months (interquartile range 62-73 months). As depicted in Figure 1, cumulative all-cause mortality at 1 year, 3 years and 5 years was respectively $5 \pm 3 \%, 17 \pm 5 \%, 22 \pm 6 \%$ for the first tertile (RAVI $\leq 19 \mathrm{ml} / \mathrm{m}^{2}$ ), $0 \%, 14 \pm 5 \%$, and $24 \pm 6 \%$ for the second tertile (RAVI $19-29 \mathrm{ml} / \mathrm{m}^{2}$ ) and $19 \pm 5 \%, 40 \pm 6 \%$, and $58 \pm 7 \%$ for the third tertile $\left(\right.$ RAVI $\left.>29 \mathrm{ml} / \mathrm{m}^{2}\right)(\mathrm{P}$ for trend $<0.001)$. All-cause mortality was higher in patients with RAVI $>29 \mathrm{ml} / \mathrm{m}^{2}$, compared to patients with either RAVI $\leq 19 \mathrm{ml} / \mathrm{m} 2(\mathrm{p}<0.001)$ or RAVI 19 to $29 \mathrm{ml} / \mathrm{m}^{2}(\mathrm{p}<0.001)$. Survival free from all-cause mortality was similar between patients with RAVI $\leq 19 \mathrm{ml} / \mathrm{m}^{2}$ compared with those with RAVI 19 to $29 \mathrm{ml} / \mathrm{m}^{2}$ ( $\left.\mathrm{p}=0.815\right)$. Consequently, survival from overall mortality was still significantly reduced in patients with RAVI $>29 \mathrm{ml} / \mathrm{m}^{2}$ compared with those with RAVI $\leq 29 \mathrm{ml} / \mathrm{m}^{2}(\mathrm{p}<0.001)$ (Figure 2A)

On multivariable analysis, there was a significant increase in mortality risk with increasing RAVI (adjusted hazard ratio [HR] 1.02 [95\% confidence interval (CI), 1.00 1.03], per $1 \mathrm{ml} / \mathrm{m}^{2}$ increment; $p=0.042$ ) (Table 2). Patients with RAVI $>29 \mathrm{ml} / \mathrm{m}^{2}$ had significantly greater risk of death compared with those with RAVI $\leq 29 \mathrm{ml} . \mathrm{m}^{2}$ (adjusted HR 2.06 [95\% CI, 1.15-3.50]; p=0.014). (Figure 2C). After further adjustment on systolic pulmonary pressure, significant tricuspid and mitral regurgitation, left atrial volume index and $\log \mathrm{BNP}$, the association between RAVI $>29 \mathrm{ml} / \mathrm{m}^{2}$ and mortality remained unchanged 
(adjusted HR 2.64 [95\% CI, 1.25-5.56]; $\mathrm{p}=0.010$ ). Adding RAVI $>29 \mathrm{ml} / \mathrm{m}^{2}$ to this fully adjusted multivariate model without RAVI $>29 \mathrm{ml} / \mathrm{m}^{2}$ improved the performance of the Cox multivariate model with an increase in the Harrell $\mathrm{C}$ statistic from 0.776 to 0.782 . Replacing TAPSE by $S^{\prime}$ in this multivariate model did not alter the strength of the relationship between RAVI $>29 \mathrm{ml} / \mathrm{m}^{2}$ and mortality (adjusted HR 2.92 [95\% CI, 1.41-6.05]; p=0.004).

As shown in Figure 2B, RAVI (> $29 \mathrm{ml} / \mathrm{m}^{2}$ or $\left.\leq 29 \mathrm{ml} / \mathrm{m}^{2}\right)$ was also associated with CV mortality. After adjustment, RAVI $>29 \mathrm{ml} / \mathrm{m}^{2}$ remained significantly associated with a significant increase in cardiovascular mortality risk (adjusted HR 3.98 [95\% CI, 1.72-9.21]) (Table 2; Figure 2D).

\section{DISCUSSION}

To the best of our knowledge, we demonstrate here for the first time that in HFrEF patients without atrial fibrillation receiving CRT, RAVI is a strong independent predictor of death. The effect of RA dilatation on outcome was powerful and remained valid after adjustment for factors known as major determinants of prognosis.

Right ventricular systolic dysfunction is associated with poor-long term prognosis in patients with HF. ${ }^{11,12}$ Baseline RV dysfunction has also been demonstrated to be associated with a poor prognosis among HFrEF patients undergoing CRT. ${ }^{3,13}$ Indeed, multiple mechanisms may negatively impact on RV contractility, including increasing afterload, ventricular interdependence, or neurohormonal activation. ${ }^{14}$ These features are usually found in advanced stages on the underlying disease. Therefore, assessment of RV function should be part of every echocardiographic examination at the time of first diagnosis of HF and during serial follow-up. However, although there have been significant improvements in RV imaging, at the era of multimodality imaging, precise assessment of RV systolic function is 
still challenging. ${ }^{1516,17}$ Therefore, it is important to acknowledge that our study used RAVI as an "easy-to-measure" highly reproducible surrogate of RV function, since reproducible quantifiable RV assessment can be limited. In our population study, RA mean values were slightly lesser than in prior studies that utilized a monoplane Simpson's rule, probably because of exclusion of patients with atrial fibrillation, as atrial enlargement can occur as a consequence of atrial fibrillation.

A strong relationship between RA volume and RV systolic dysfunction has been previously demonstrated. ${ }^{7}$ Increased RAVI may predict low functional capacity, especially in the subgroup of patients with RV systolic dysfunction. ${ }^{18} \mathrm{RV}$ impairment secondary to LV failure is usually a consequence of pressure overload, which is translated to RV pressure and tricuspid regurgitation, and evolves to $\mathrm{RV}$ and atrial dilatation. Then, impaired $\mathrm{RV}$ contractility may cause compensatory elevated RA volume for increasing blood volume reservoir. ${ }^{19}$ However, the pathophysiology of elevated RA volume in HFrEF is not fully understood, and it is unclear if RA volume has a direct effect on impaired hemodynamics, more than just being a surrogate of severity in chronic HF. Few studies have investigated the prognostic impact of RA enlargement in $\mathrm{HFrEF}^{7}$ In our population study, patients with elevated RA volume shared as expected clinical, biological and echocardiographic features of a more advanced stage of HF. Interestingly, in our population study, increased RA volume was not exclusively associated with RV systolic dysfunction but also with LA dilation, significant MR and TR. This could suggest that RA dilatation may reflect a more severe global clinical presentation and/or advanced stage in patients with HFrEF, independently from RV function. Therefore, the results of the present study suggest that patients with increased RA size before CRT should be carefully monitored, in order to insure timely referral for advanced therapy (heart transplantation, left ventricular assist device....) before worsening of 
their clinical condition.

Whereas echocardiograms were prospectively collected, follow-up data were obtained retrospectively. Moreover, all patients with HFrEF from the present report received CRT; hence, the present data cannot be fully extrapolated to the broad population of patients with HF. We purposefully used mortality which is an unbiased endpoint in contrast to hospitalization for heart failure during follow up, which is highly influenced by salt intake and adherence to medications. The measurement of RAV on the apical 4-chamber view places the RA in the far field, diminishing lateral resolution and adversely affecting visualization of its endocardium. However, a strong correlation has been shown between estimation of RAV by this method and cardiac MRI. ${ }^{20}$

In conclusion, our study shows that RA enlargement is independently predictive of long-term mortality in patients with HF with reduced ejection fraction in sinus rhythm receiving cardiac resynchronization therapy. Detection of RAVI $>29 \mathrm{ml} / \mathrm{m}^{2}$ is associated with major increase in the risk of death during follow-up. 


\section{Figure legends}

Figure 1. Kaplan Meier event-free survival for overall mortality according to right atrial volume index (RAVI) tertiles (A).

Figure 2. Kaplan Meier event-free survival for overall and cardiovascular mortality according to right atrial volume index RAVI $\leq 29 \mathrm{ml} / \mathrm{m}^{2}$ and RAVI $>29 \mathrm{ml} / \mathrm{m}^{2}$ (A and B). Cumulative hazard of overall (C) and cardiovascular (D) mortality according to right atrial volume index $\mathrm{RAVI} \leq 29 \mathrm{ml} / \mathrm{m}^{2}$ and RAVI $>29 \mathrm{ml} / \mathrm{m}^{2}$ 


\section{REFERENCES}

1. Meyer P, Filippatos GS, Ahmed MI, Iskandrian AE, Bittner V, Perry GJ, White M, Aban IB, Mujib M, Dell'Italia LJ, Ahmed A. Effects of right ventricular ejection fraction on outcomes in chronic systolic heart failure. Circulation 2010;121:252-258.

2. Venkatachalam S, Wu G, Ahmad M. Echocardiographic assessment of the right ventricle in the current era: Application in clinical practice. Echocardiography 2017;34:1930-1947.

3. Leong DP, Hoke U, Delgado V, Auger D, Witkowski T, Thijssen J, van Erven L, Bax JJ, Schalij MJ, Marsan NA. Right ventricular function and survival following cardiac resynchronisation therapy. Heart 2013;99:722-728.

4. Sharma A, Bax JJ, Vallakati A, Goel S, Lavie CJ, Kassotis J, Mukherjee D, Einstein A, Warrier N, Lazar JM. Meta-Analysis of the Relation of Baseline Right Ventricular Function to Response to Cardiac Resynchronization Therapy. The American journal of cardiology 2016;117:1315-1321.

5. Haddad F, Hunt SA, Rosenthal DN, Murphy DJ. Right ventricular function in cardiovascular disease, part I: Anatomy, physiology, aging, and functional assessment of the right ventricle. Circulation 2008;117:1436-1448.

6. Sato T, Tsujino I, Ohira H, Oyama-Manabe N, Ito YM, Yamada A, Ikeda D, Watanabe T, Nishimura M. Right atrial volume and reservoir function are novel independent predictors of clinical worsening in patients with pulmonary hypertension. J Heart Lung Transplant 2015;34:414-423.

7. Sallach JA, Tang WH, Borowski AG, Tong W, Porter T, Martin MG, Jasper SE, Shrestha K, Troughton RW, Klein AL. Right atrial volume index in chronic systolic heart failure and prognosis. JACC Cardiovasc Imaging 2009;2:527-534. 
8. Lang RM, Badano LP, Mor-Avi V, Afilalo J, Armstrong A, Ernande L, Flachskampf FA, Foster E, Goldstein SA, Kuznetsova T, Lancellotti P, Muraru D, Picard MH, Rietzschel ER, Rudski L, Spencer KT, Tsang W, Voigt JU. Recommendations for cardiac chamber quantification by echocardiography in adults: an update from the American Society of Echocardiography and the European Association of Cardiovascular Imaging. European heart journal cardiovascular Imaging 2015;16:233-270.

9. Binda C, Menet A, Appert L, Ennezat PV, Delelis F, Castel AL, Le Goffic C, Guyomar Y, Ringle A, Guerbaai RA, Graux P, Tribouilloy C, Marechaux S. Time course of secondary mitral regurgitation in patients with heart failure receiving cardiac resynchronization therapy: Impact on long-term outcome beyond left ventricular reverse remodelling. Archives of cardiovascular diseases 2018;111:320-331.

10. Lancellotti P, Moura L, Pierard LA, Agricola E, Popescu BA, Tribouilloy C, Hagendorff A, Monin JL, Badano L, Zamorano JL, European Association of E. European Association of Echocardiography recommendations for the assessment of valvular regurgitation. Part 2: mitral and tricuspid regurgitation (native valve disease). Eur J Echocardiogr 2010;11:307332.

11. de Groote P, Millaire A, Foucher-Hossein C, Nugue O, Marchandise X, Ducloux G, Lablanche JM. Right ventricular ejection fraction is an independent predictor of survival in patients with moderate heart failure. Journal of the American College of Cardiology 1998;32:948-954.

12. Ennezat PV, Marechaux S, Huerre C, Deklunder G, Asseman P, Jude B, Van Belle E, Mouquet F, Bauters C, Lamblin N, Lejemtel TH, de Groote P. Exercise does not enhance the prognostic value of Doppler echocardiography in patients with left ventricular systolic dysfunction and functional mitral regurgitation at rest. Am Heart J 2008;155:752-757. 
13. Damy T, Ghio S, Rigby AS, Hittinger L, Jacobs S, Leyva F, Delgado JF, Daubert JC, Gras D, Tavazzi L, Cleland JG. Interplay between right ventricular function and cardiac resynchronization therapy: an analysis of the CARE-HF trial (Cardiac ResynchronizationHeart Failure). J Am Coll Cardiol 2013;61:2153-2160.

14. Vonk Noordegraaf A, Westerhof BE, Westerhof N. The Relationship Between the Right Ventricle and its Load in Pulmonary Hypertension. J Am Coll Cardiol 2017;69:236-243.

15. Peyrou J, Parsai C, Chauvel C, Simon M, Dehant P, Abergel E. Echocardiographic assessment of right ventricular systolic function in a population of unselected patients before cardiac surgery: a multiparametric approach is necessary. Arch Cardiovasc Dis 2014;107:529539.

16. Csecs I, Czimbalmos C, Suhai FI, Mikle R, Mirzahosseini A, Dohy Z, Szucs A, Kiss AR, Simor T, Toth A, Merkely B, Vago H. Left and right ventricular parameters corrected with threshold-based quantification method in a normal cohort analyzed by three independent observers with various training-degree. Int J Cardiovasc Imaging 2018.

17. Nagata Y, Wu VC, Kado Y, Otani K, Lin FC, Otsuji Y, Negishi K, Takeuchi M. Prognostic Value of Right Ventricular Ejection Fraction Assessed by Transthoracic 3D Echocardiography. Circ Cardiovasc Imaging 2017;10.

18. Mantziari L, Kamperidis V, Ventoulis I, Damvopoulou E, Giannakoulas G, Efthimiadis G, Paraskevaidis S, Vassilikos V, Ziakas A, Karvounis H, Styliadis IH. Increased right atrial volume index predicts low Duke activity status index in patients with chronic heart failure. Hellenic J Cardiol 2013;54:32-38.

19. Gaynor SL, Maniar HS, Prasad SM, Steendijk P, Moon MR. Reservoir and conduit function of right atrium: impact on right ventricular filling and cardiac output. Am J Physiol Heart Circ Physiol 2005;288:H2140-2145. 
20. Ebtia M, Murphy D, Gin K, Lee PK, Jue J, Nair P, Mayo J, Barnes ME, Thompson DJ, Tsang TS. Best method for right atrial volume assessment by two-dimensional echocardiography: validation with magnetic resonance imaging. Echocardiography 2015;32:734-739. 


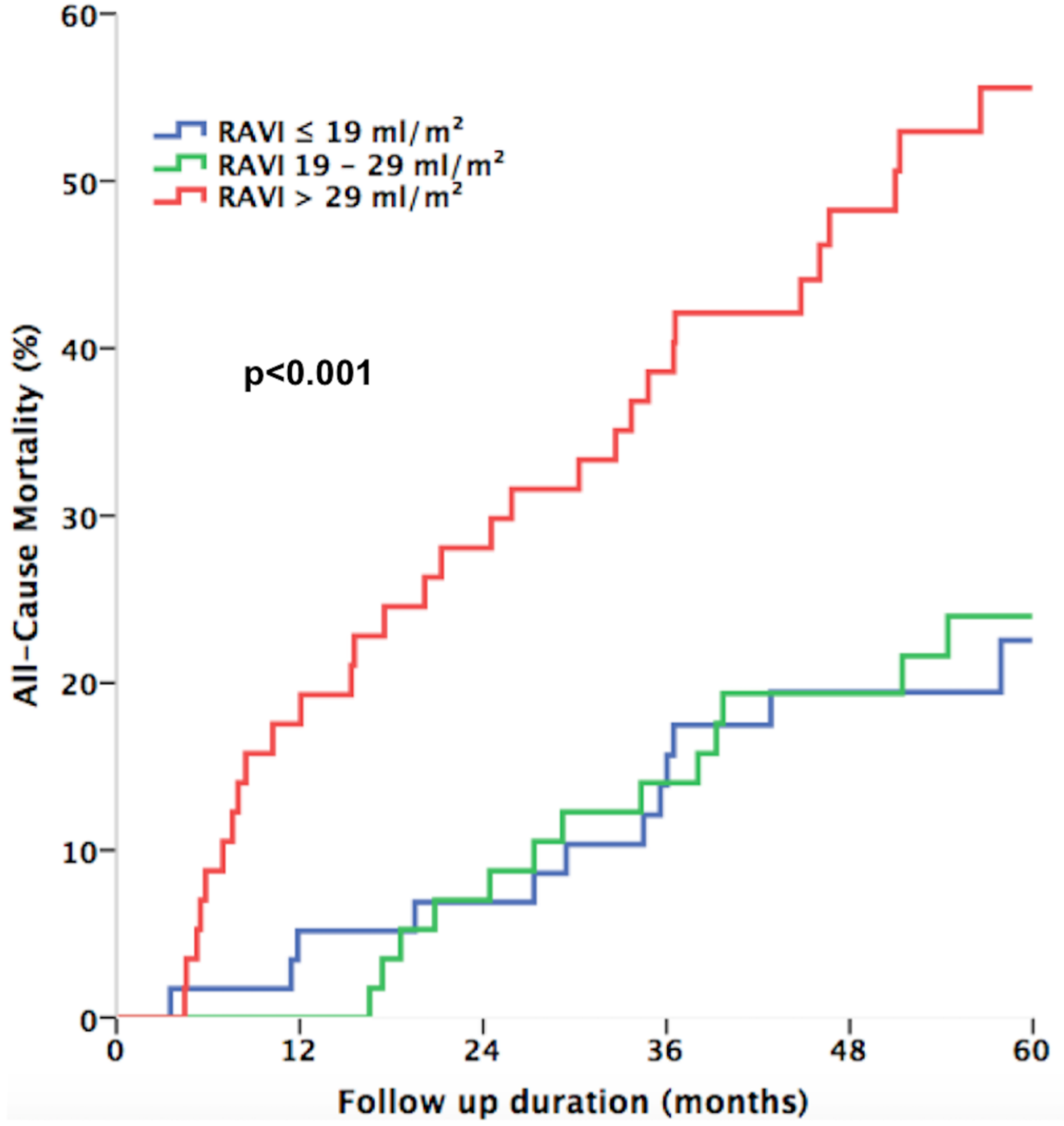

Number at risk

\begin{tabular}{rlllll}
58 & 56 & 54 & 50 & 36 & 23 \\
57 & 57 & 53 & 49 & 40 & 29 \\
57 & 47 & 41 & 35 & 24 & 16 \\
\hline 0 & 12 & 24 & 36 & 48 & 60
\end{tabular}




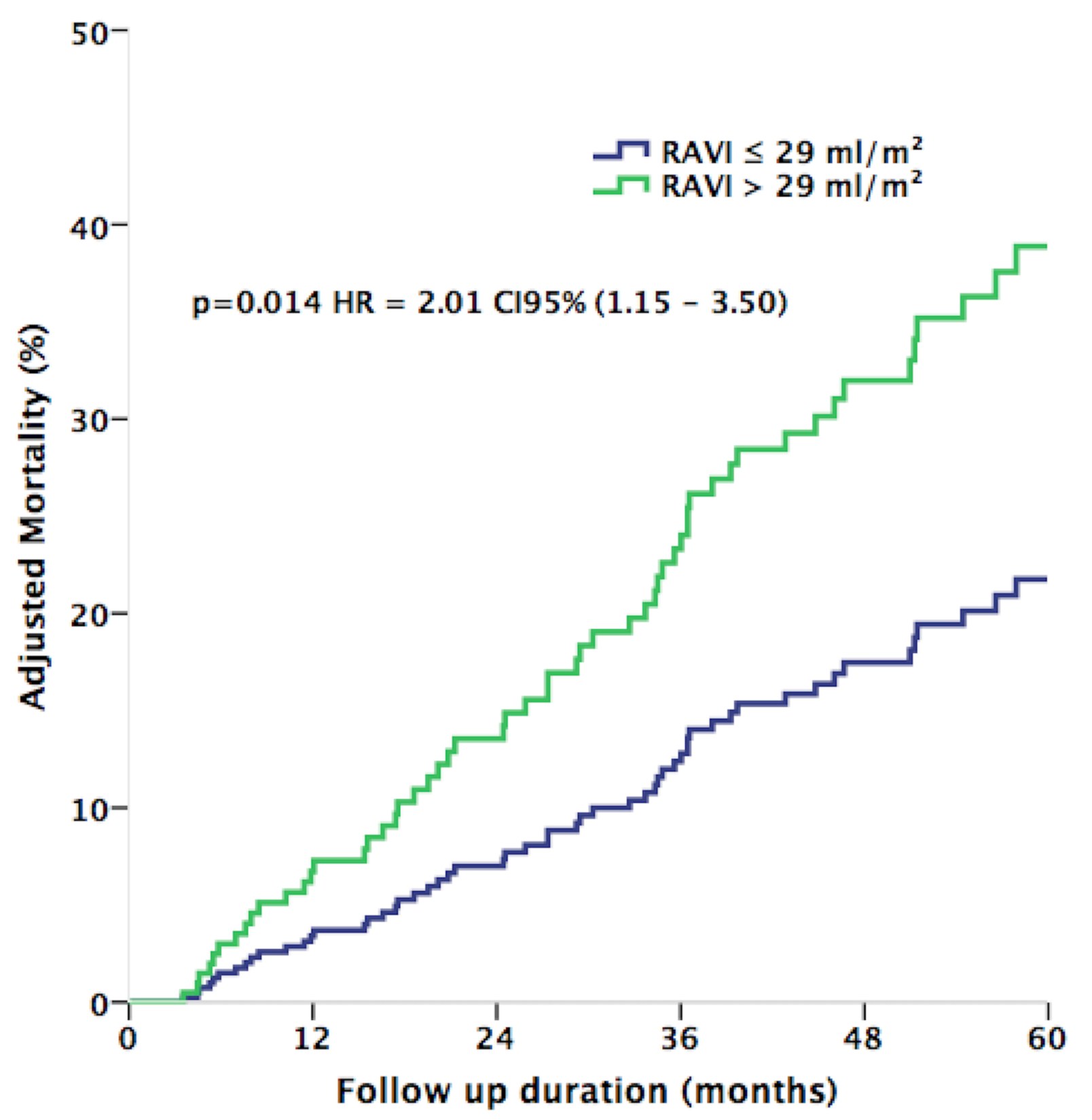




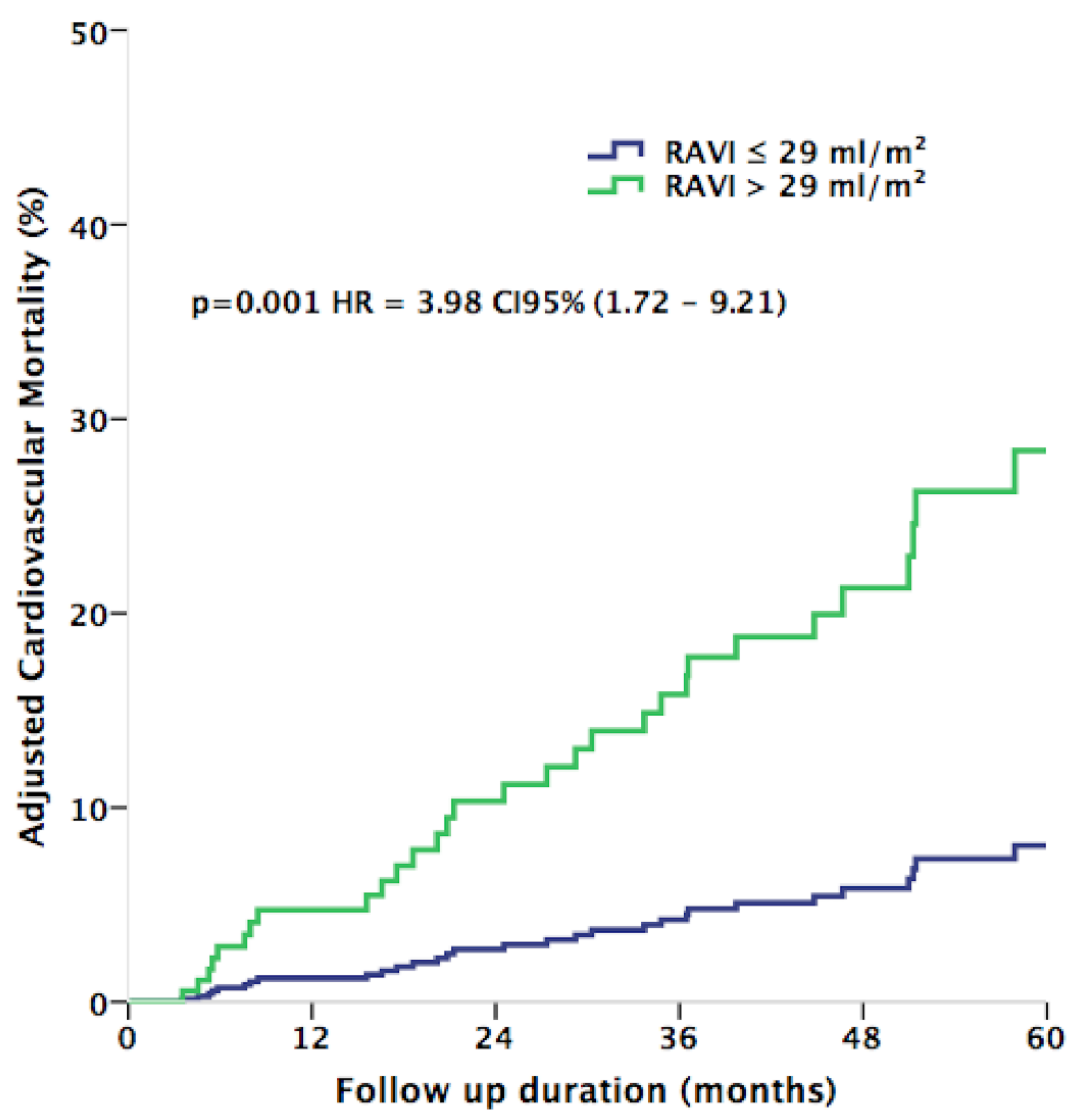




\begin{tabular}{|c|c|c|c|c|c|}
\hline & \multicolumn{5}{|c|}{$\operatorname{RAVI}\left(\mathbf{m L} / \mathbf{m}^{2}\right)$} \\
\hline & All & $\leq 19$ & 19 to 29 & $>29$ & P-value \\
\hline \multicolumn{6}{|l|}{ Variable } \\
\hline Age (years) & $70 \pm 11$ & $69 \pm 11$ & $69 \pm 11$ & $74 \pm 11$ & 0.026 \\
\hline Men & $119(69 \%)$ & $37(64 \%)$ & $36(63 \%)$ & $46(81 \%)$ & 0.070 \\
\hline Body mass index $\left(\mathrm{kg} / \mathrm{m}^{2}\right)$ & $27 \pm 5$ & $28 \pm 6$ & $27 \pm 5$ & $26 \pm 4$ & 0.167 \\
\hline Body surface area $\left(\mathrm{m}^{2}\right)$ & $1.89 \pm 0.24$ & $1.91 \pm 0.23$ & $1.90 \pm 0.27$ & $1.87 \pm 0.22$ & 0.590 \\
\hline Hypertension & $75(43 \%)$ & $26(45 \%)$ & $26(46 \%)$ & $23(40 \%)$ & 0.829 \\
\hline Diabetes mellitus & $52(30 \%)$ & $21(36 \%)$ & $17(30 \%)$ & $14(25 \%)$ & 0.396 \\
\hline Dyslipidemia & $68(39 \%)$ & $23(40 \%)$ & $25(44 \%)$ & $20(35 \%)$ & 0.632 \\
\hline Coronary Artery Disease & $67(39 \%)$ & $20(34 \%)$ & $25(44 \%)$ & $22(39 \%)$ & 0.586 \\
\hline NYHA functional class III-IV & $83(48 \%)$ & $19(33 \%)$ & $26(46 \%)$ & $38(67 \%)$ & 0.001 \\
\hline Heart rate (b.p.m.) & $71 \pm 11$ & $70 \pm 10$ & $69 \pm 9$ & $75 \pm 14$ & 0.023 \\
\hline Systolic Blood Pressure (mmHg) & 120 [110-135] & $120[110-130]$ & 120 [110-140] & 115 [100-130] & 0.003 \\
\hline Diastolic Blood Pressure (mmHg) & $70[60-80]$ & $70[60-80]$ & $70[60-80]$ & 70 [60-77] & 0.236 \\
\hline QRS width (ms) & $160[150-180]$ & $160[150-180]$ & $160[150-175]$ & $160[152-190]$ & 0.462 \\
\hline Left bundle branch block & $136(79 \%)$ & $51(88 \%)$ & $44(77 \%)$ & $41(72 \%)$ & 0.099 \\
\hline Implantable cardioverter defibrillator & $142(83 \%)$ & $53(91 \%)$ & $57(82 \%)$ & $42(74 \%)$ & 0.044 \\
\hline Mineralocorticoid receptors antagonists & $49(28 \%)$ & $17(29 \%)$ & $14(25 \%)$ & $18(32 \%)$ & 0.698 \\
\hline Use of diuretics & $135(78 \%)$ & $44(76 \%)$ & $38(67 \%)$ & $53(93 \%)$ & 0.002 \\
\hline Beta blockers & $152(88 \%)$ & $55(95 \%)$ & $50(87 \%)$ & $47(82 \%)$ & 0.115 \\
\hline $\begin{array}{l}\text { Angiotensin-converting enzyme } \\
\text { inhibitors/Angiotensin receptor blocker }\end{array}$ & $153(89 \%)$ & $53(91 \%)$ & $50(88 \%)$ & $50(88 \%)$ & 0.769 \\
\hline Creatinine $(\mathrm{mg} / \mathrm{dL})$ & $11[9-14]$ & $10[9-14]$ & $10[8-13]$ & 13 [11-19] & $<0.001$ \\
\hline $\mathrm{BNP}(\mathrm{pg} / \mathrm{mL})$ & 384 [144-879] & $207[91-410]$ & 316 [128-778] & $760[416-1556]$ & $<0.001$ \\
\hline Left ventricular ejection fraction (\%) & $26 \pm 5$ & $29 \pm 5$ & $28 \pm 4$ & $24 \pm 5$ & $<0.001$ \\
\hline Left ventricular end-diastolic diameter (mm) & $67 \pm 8$ & $66 \pm 9$ & $66 \pm 8$ & $68 \pm 8$ & 0.296 \\
\hline Left ventricular end-systolic diameter (mm) & $57 \pm 10$ & $56 \pm 11$ & $56 \pm 9$ & $59 \pm 8$ & 0.153 \\
\hline Left ventricular end-diastolic volume (mm) & 243 [201-296] & 231 [189-289] & 222 [197-284] & 269 [212-301] & 0.037 \\
\hline Left ventricular end-systolic volume (mm) & $175[143-222]$ & $171[136-210]$ & 164 [142-201] & 193 [163-245] & 0.011 \\
\hline Left atrial volume index (m1/m2) & $37 \pm 13$ & $32 \pm 11$ & $36 \pm 12$ & $44 \pm 11$ & $<0.001$ \\
\hline $\mathrm{E} / \mathrm{e}^{\prime}$ ratio & $12[10-17]$ & $11[9-17]$ & $12[9-15]$ & 15 [10-19] & 0.040 \\
\hline E/A ratio & $1.0[0.6-1.8]$ & $0.7[0.6-1.1]$ & $0.9[0.6-1.3]$ & $1.7[0.8-2.3]$ & $<0.001$ \\
\hline Myocardial scar & $25(14 \%)$ & $8(14 \%)$ & $8(14 \%)$ & $9(16 \%)$ & 0.947 \\
\hline $\begin{array}{l}\text { Mitral regurgitation Effective regurgitant } \\
\text { orifice area }>10 \mathrm{~mm}^{2}\end{array}$ & $36(21 \%)$ & $7(12 \%)$ & $6(10 \%)$ & $23(40 \%)$ & $<0.001$ \\
\hline $\operatorname{RAVI}\left(\mathrm{ml} / \mathrm{m}^{2}\right)$ & $27 \pm 14$ & $15 \pm 3$ & $23 \pm 3$ & $42 \pm 13$ & $\begin{array}{c}\text { By } \\
\text { design }\end{array}$ \\
\hline $\begin{array}{l}\text { Tricuspid annular plane systolic excursion } \\
(\mathrm{mm})\end{array}$ & $20 \pm 5$ & $21 \pm 4$ & $22 \pm 5$ & $18 \pm 5$ & 0.001 \\
\hline $\begin{array}{l}\text { Doppler-derived tricuspid annular systolic } \\
\text { velocity }(\mathrm{cm} / \mathrm{s})\end{array}$ & $10 \pm 3$ & $10 \pm 3$ & $10 \pm 3$ & $9 \pm 3$ & 0.015 \\
\hline Systolic pulmonary arterial pressure $(\mathrm{mmHg})$ & 34 [24-45] & 28 [23-36] & $28[23-38]$ & $43[34-51]$ & $<0.001$ \\
\hline Tricuspid regurgitation $\geq$ moderate to severe & $14(8 \%)$ & $2(3 \%)$ & $2(3 \%)$ & $10(17 \%)$ & 0.013 \\
\hline
\end{tabular}

Table 1. Baseline demographic, clinical, laboratory and echocardiographic data in the study population and according to right atrial volume index (RAVI) tertiles 
Table 2: Relationship between right atrial volume index RAVI $>29 \mathrm{ml} / \mathrm{m}^{2}$ and all-cause mortality, cardiovascular mortality by Cox analysis.

\begin{tabular}{|c|c|c|c|c|c|}
\hline & & \multicolumn{2}{|c|}{ All-cause mortality } & \multicolumn{2}{|c|}{ Cardiovascular mortality } \\
\hline \multirow{3}{*}{$\begin{array}{l}\text { Univariate } \\
\text { analysis }\end{array}$} & & HR(CI 95\%) & $\mathbf{p}$ & HR(CI 95\%) & $\mathbf{p}$ \\
\hline & $\begin{array}{l}\text { RAVI (per } 1 \mathrm{ml} / \mathrm{m}^{2} \\
\text { increment) }\end{array}$ & $1.04(1.02-1.05)$ & $<0.001$ & $1.05(1.03-1.07)$ & $<0.001$ \\
\hline & $\mathrm{RAVI}>29 \mathrm{ml} / \mathrm{m}^{2}$ & $3.61(2.20-5.94)$ & $<0.001$ & $7.68(3.57-16.53)$ & $<0.001$ \\
\hline \multirow{10}{*}{$\begin{array}{c}\text { Multivariate } \\
\text { analysis }\end{array}$} & & $\begin{array}{c}\text { Adjusted HR (CI } \\
95 \%)\end{array}$ & $\mathbf{p}$ & $\begin{array}{c}\text { Adjusted HR (CI } \\
\text { 95\%) }\end{array}$ & $\mathbf{p}$ \\
\hline & $\mathrm{RAVI}>29 \mathrm{ml} / \mathrm{m}^{2}$ & $2.01(1.15-3.50)$ & 0.014 & $3.98(1.72-9.21)$ & 0.001 \\
\hline & Age & $1.05(1.02-1.08)$ & 0.001 & $1.04(1.00-1.08)$ & 0.035 \\
\hline & QRS width & $0.99(0.98-1.00)$ & 0.151 & $0.99(0.98-1.01)$ & 0.241 \\
\hline & $\begin{array}{l}\text { NYHA functional class } \\
\text { III/IV }\end{array}$ & $1.91(1.09-3.36)$ & 0.023 & $141(0.80-3.68)$ & 0.158 \\
\hline & Coronary artery disease & $1.38(0.84-2.28)$ & 0.203 & $1.35(0.68-2.68)$ & 0.848 \\
\hline & Creatinine serum & $1.05(1.02-1.08)$ & 0.003 & $1.05(1.01-1.10)$ & 0.017 \\
\hline & LV ejection fraction & $0.96(0.91-1.02)$ & 0.181 & $0.94(0.87-1.02)$ & 0.144 \\
\hline & $\begin{array}{l}\text { Left bundle branch } \\
\text { block }\end{array}$ & $0.92(0.50-1.69)$ & 0.798 & $1.60(0.64-3.94)$ & 0.311 \\
\hline & $\begin{array}{l}\text { Tricuspid Annular } \\
\text { Plane Systolic } \\
\text { Excursion }\end{array}$ & $0.92(0.50-1.69)$ & 0.120 & $0.93(0.86-1.00)$ & 0.063 \\
\hline
\end{tabular}

